\title{
Political Speech in Fantastical Worlds
}

\author{
PAUl KiRBY \\ University of Sussex
}

\begin{abstract}
"To think of these stars that you see overhead at night, these vast worlds that we can never reach. I would annex the planets if I could; I often think of that. It makes me sad to see them so clear and yet so far."
\end{abstract}

- Cecil Rhodes (in Stead 1902, 190)

"[W]hen people ask me, Why do you write about men ... I say, because I like to write about aliens. It's very flip, it's also very true. I'm fascinated by this attempt to get into the Other."

- Ursula K. Le Guin (in Delany 1977, 277)

\section{$\underline{\text { Speculative Frictions }}$}

Cecil Rhodes was a fervent advocate of imperial expansion, and yet confessed himself unsatisfied by the territories of the earth. ${ }^{1}$ Ursula K. Le Guin, opposed to Rhodes in matters of politics, nevertheless cast radicalism in extra-planetary terms. Rhodes the imperialist belongs to the true history of blood and conquest, but dreamt of the impossible. Le Guin the author explores the ideological predicaments of the 20th century by removing her protagonists from any recognisable timeline. ${ }^{2}$ Both imagined the stars as an extension of the earth by other means, a speculative antechamber, catacomb and satellite, in ceaseless communion with worldly politics.

The admixture of the political and the fantastical is no novelty. Science fiction and its cousins have always been understood as disruptive and potentially subversive, most obviously when they served as satires on great persons or forewarnings of disaster, but also as summations of

1 Ronnie Lipschutz notes a similar tendency in the 20th century Westphalian imagination writ large: "the stars offered a vista of limitless lebensraum" $(2003,79)$.

2 Le Guin is equally famous as the author of the Earthsea fantasy series (starting with A Wizard of Earthsea in 1968) and such works of science fiction as The Left Hand of Darkness (1969), The Lathe of Heaven (1971) and The Dispossessed (1974). 
the mood of an epoch. There has always been reason, as Brian Aldiss recalled of the 1960s, "to think of SF as ammunition in a global battle". ${ }^{3}$ Today, the observation that non-realist fiction may be read politically is, if anything, a commonplace. In the fragmented quasidiscipline of International Relations (IR), pop cultural scholarship has evolved from a minority to a mainstream pursuit. ${ }^{4}$ And of all the forms of cultural narrative taken up by IR, science or speculative fiction (SF or sf) has been the most popular. ${ }^{5}$ An emergent sub-subfield its own right, the interface of SF and IR (henceforth SF/IR) exemplifies a spreading pluralism of topic and method. IR engages SF at multiple depths: as a teaching aid (e.g. Drezner 2011; Weber 2001; Ruane and James 2012; Clapton and Shepherd 2016); as a way to communicate IR concepts to a broader public (e.g. Carpenter 2012; Sterling-Folker and Folker 2006); and as a field for analysis in its own right (e.g. Dittmer 2013; Shepherd 2013). At each level, it is supposed that fundamental features of politics - the contest over which persons and collectives may exercise power, and over whom - are expressed with a certain force by an artistic genre that at first glance present worlds radically different from our own. Through the fantastical and the speculative, political speech is conveyed outside of itself.

This article presents a critical survey of recent developments in SF/IR, in the process disjointing some common understandings of the inherence of politics in speculative fiction and the inheritance of speculative fiction for politics. Since few practitioners of SF/IR ascend from the particular to consider cultural circulation at large, studies of individual cultural texts or serials (e.g. Star Trek, Game of Thrones, Captain America) have proliferated, and in turn been received with indifference or derision from scholars who do not see the relevance for political science. The relation of cultural products (books, television shows, and films, but

3 Aldiss 2013, 29.

4 The greater acceptance can be charted in several developments. There is now a 'Pop Culture and World Politics' monograph series, an annual conference of the same name, a range of edited collections on specific TV shows, films and comic superheroes, a number of pop cultural syllabi taught in IR and political science departments, and original articles on pop cultural phenomenon can be found in the pages of journals like Politics, Security Dialogue, The National Interest and even Foreign Affairs (if only thus far online in the case of the latter two). Early attention to the political salience of art and culture is often traced to Bleiker 2001; cf. Shapiro 1997; Weber 1999; Weldes 1999; see also Amaturo 1995 and the discussion in Holden 2003.

5 'Speculative fiction' is a sometimes abbreviated in lowercase form as 'sf' to distinguish it from the more common 'SF' designating 'science fiction'. I explore issues of terminology below, but use SF throughout to mean speculative fiction in the broadest sense, unless otherwise specified. 
also songs, plays, operas, poems, computer games, sculpture, fine and conceptual art) to political events can be thought of in a multitude of ways: as commentary, profanity, echo, allegory, complaint, celebration, mischief, mimicry and more besides. ${ }^{6}$ And yet, as I hope to show, academic IR tends towards monolithic readings, often inattentive to genre conventions and subversions, to narrative ambiguity or the historical context that shaped a work, and to divergent audience responses or the vagaries of textual reinterpretation.

I argue both that SF and fantasy are intimate correlates of political thought, and that significant swathes of pop cultural IR are reductive in their causal, constitutive and normative judgements of speculative fiction. A first section sets out the status of the SF genre(s) for international political inquiry. The case has been made before, but is here presented with greater ambition, paying particular attention to utopia, and arguing for a view of speculative fiction as a hinterland of political theory. Against those who invoke 'utopia' as an epithet or who trace the speculative only insofar as it appears in official political discourse, I propose that utopian fictions are both less distinctive and more ubiquitous than commonly thought. They represent in miniature a tension between disciplined and undisciplined social dreaming that affects SF and pop culture at large. In the second part, the underlying rationale for the interpretation of SF in IR is revisited, and some of its standard motifs recapitulated. Having expanded the field of inquiry, a third section demonstrates the limits of analogical analysis as currently practiced. More than a criticism of descriptive analogies, the section shows how similar issues of reductionism afflict some - but not all - self-consciously critical studies.

Where it has often been claimed that SF teaches us about world politics in some direct sense, I subscribe to an alternative view. Rather than the notion of SF as a 'mirror' for IR, I explore oblique geometry, asymmetry, inversion and paradox as characteristic of their relationship. In this I follow others who have used SF as an acerbic metaphor for disciplinary failings (Weber 1999), traced political aesthetics though the uncanny technologies and framings that produce them (Shapiro 2009), mapped simultaneous, clashing modes of reading cultural artefacts (Neumann and Nexon 2006), or defended a radical openness in deciding just what

\footnotetext{
6 Although I am unable to explore the full variety of cultural products and their effects here, see in particular Baudrillard 1995; Der Derian 2009; Salter 2011; Brennan 2015.
} 
representations 'really' convey (see Segal 1998). In this vein, the fourth substantive section elaborates and defends a new distinction between programmatic and expressive sensibilities in SF. The distinction works to clarify the tension between disciplined and undisciplined dreaming with which the article begins, underlining the point via SF examples and a series of arguments drawn from literary criticism. Having mapped the current limits of pop-cultural $\mathrm{SF} / \mathrm{IR}$, and offered some alternative coordinates, the final section draws out general implications for method and the research ethic. The corrective is intended to revive a sense of ambivalence in IR's pop cultural analytic: both in terms of the content of speculative fictions and in the means by which they are absorbed into a larger universe of aesthetics and power.

\section{Old Maps of Hell ${ }^{7}$}

What special qualities do science and speculative fiction offer up to the student of politics? Following the SF author and critic Samuel R. Delany, we can usefully distinguish between genres in terms of the tension (or the tense-sion) which invests their texts with meaning: what Delany calls their subjunctivity (see also Russ 1995, 15-25). In naturalistic fiction, the implicit background to the plot is always that this could have happened. This understanding structures the expectations of the reader, which in aggregate become genre conventions. Plots that deviate from that logic will jar, and so regarded as failures on artistic grounds or recategorised as belonging to another style. For reportage, the subjunctive tense is that this actually happened. The yardstick of value is fidelity to events. By contrast, for fantasy, we understand that this could not have happened. The protagonists are not only magical, but exist in some era long past, or outside of time. For science fiction, the subjunctivity is that this has not happened. SF thus includes stories about events that might happen, that will not happen, that haven't happened yet, and that have not happened in the past (the special case of the parallel universe story) (Delany 1977, 31-33).

Beneath this typology, there are many possible refinements, schools of space opera, cyber and steam punk, new weird, alternative history, afro-futurism, time travel, science fantasy,

7 With apologies to Amis 2012. 
military, gothic, techno-noir, doomsday, post-apocalypse, and further subdivisions or combinations thereof. Interminable debates simmer over the nature of the distinction between 'fantasy' and 'science fiction' and how they may legitimately intermingle. ${ }^{8}$ While some branches of SF focus on technical elements of the future, others narrate 'inner space': experiences of terror, alienation, and antagonism that do not depend on scientific precepts per se, and which bleed into the fantastical in their staging. The orientation of science fiction as a whole is thus not reducible to either its 'scientific' or 'fictional' content. ${ }^{9}$ The now common denotation of the field as 'speculative' is an acknowledgement of a genre border trouble, a compromise on family resemblance to suppress internecine warfare. For the purposes of the coming argument, 'speculative fiction' or SF thus includes science fiction of various kinds as well as fantasy and fantastical allegory. My analysis is promiscuous, taking in examples from science fiction, speculative fiction, fantasy and horror, as well as their seepages into each other. This is quite deliberate: since the discrete analysis of individual texts has predominated in SF/IR, and since it is part of my argument that such an approach is reductionist, I have instead relied on an archipelago of examples, in an attempt to convey the mobility of SF tropes and reinforce the impression of culture as a fragmentary inter-text (see Shapiro 1989; Weldes 2001; Long 2006).

Speculative fiction is but one variety of imaginative work, its cultural domain both recognised and contested. It can be found in the pulp of Amazing Stories magazine, the seminal Frankenstein of Mary Shelley, the zen absurdism of Kurt Vonnegut, the space fantasy epic Star Wars, the dystopian modernity of J.G. Ballard, the technological blueprints of Arthur C. Clarke, and the feminist futures-past of Margaret Atwood. Contemporary western culture places major works of speculative fiction at the heart of a humanist education: Atwood's The Handmaid's Tale, Ray Bradbury's Fahrenheit 451, Vonnegut's Slaughterhouse Five, Anthony Burgess' A Clockwork Orange, Aldous Huxley's Brave New World, George Orwell's

8 There is no serious treatment of science fiction that does not fret over these questions. Excepting the typology offered by Delany, astute or entertaining discussions can be found in Amis 2012; Freedman 1987; Jackson 1981.

9 For some, feminist science fiction is not, in general, a science fiction at all because it addresses culture where male SF celebrates only control over nature (Barr 1987, 187). It is generally accepted that the 'science' element in SF may be starkly lacking in credentials, better thought of as following the impulse of the 'scientific spirit' (Williams 1978, 204) or as establishing the narrative effect of scientific plausibility (Miéville 2009). 
Nineteen-Eighty Four, Daniel Keyes' Flowers for Algernon, and William Golding's Lord of the Flies all feature prominently in school syllabi. ${ }^{10}$ Moreover, although it is common to dismiss SF as not real Literature (or to claim that SF is so dismissed - see Barr, 2004), acknowledged luminaries as diverse as E.M. Forster, Kingsley Amis, Virginia Woolf, W.E.B. Du Bois, Philip Roth, Voltaire, P. D. James, Kazuo Ishiguro, Nadine Gordimer, Vladimir Nabokov, Gore Vidal, Salman Rushdie, Doris Lessing, Thomas Pynchon and Orwell have all dabbled in or mastered the speculative. ${ }^{11}$

For the socially-conscious consumer of SF as literature, its politics deserve scrutiny precisely because what we enjoy marks the boundary of who we are. When fantastical political speech is understood as an echo of real social conflicts, the estranged setting of the novel (and later the film and television episode) becomes a vehicle through which the author may obfuscate and so reproduce their political views, smuggling them across the border of legitimacy under the counterfeit passport of 'fiction'. From this springs fan anxieties over the implications of cultural consumption: for example, is Batman fascist? (Yogerst 2013; Mamatas 2008). For the scholar of global politics, the rationale for scrutiny is somewhat different. Excluding the question of whether it makes IR concepts easier to explain to students (a pedagogical strategy, rather than a research programme), SF must offer some kind of analytical purchase for the exercise to be more than fan fiction by proxy.

Yet the obvious irreality of SF casts immediate doubt on its utility, as compared to texts that report directly on events (see, e.g. Dyvik 2015 on military memoirs and Dauphinee 2013 and Inayatullah and Dauphinee 2016 on narrative). Although held in higher regard than it once was, speculative fiction is still often considered frivolous, a variety of escapism and therefore irrelevant to political inquiry in direct proportion to its distance from contemporary events.

10 Whilst there are always other classifications available, Lord of the Flies is reasonably considered a science fiction allegory (Amis 2012, 114-115).

11 In 'The Machine Stops', The Alteration, Orlando: A Biography, 'The Comet', The Plot Against America, 'Micromégas', The Children of Men, Never Let Me Go, July's People, The Waltz Invention, Visit to a Small Planet, Grimus, Shikasta, Against The Day and Nineteen Eighty-Four respectively. The last is shelved along with the high literature, but has features of science fiction, although not features enough for Isaac Asimov, who denounced it memorably as "not science fiction, but a distorted nostalgia for a past that never was" (1981). Several of these authors produced more than one tale of speculative fiction, whilst remaining exponents of literature proper in most catalogues. See also the discussion in Disch 1998, 2-5. 
Yet for some of its advocates, it is precisely the fidelity to reality - to reasoned extrapolations from the present into the future - which makes science fiction a useful instrument with which to reflect on politics. In an early IR view of SF, Dennis Livingston saw in it the technical skills of futurology swilled together with the "unquantifiable ingredient" of imagination (Livingston 1971, 255), an edge denied to purveyors of more respectable forecasts. For their part, the preeminent futurologists of the time were as indebted to mysticism as they were to hyper-rationalism (Williams 2016).

SF thus both predicts, and indeed causes, futures (Disch 1998; cf. Sargent 1994, 26-28; Carpenter 2016). As some saw it, what was science fiction to the 1940s was science fact by the 1960s." ${ }^{12}$ But the idea of SF as prediction, which Harlan Ellison simply calls "pure bullshit", is only one possible intellectual trajectory. ${ }^{13}$ Not only is there more to SF than political forecasting by another name, but this supposed 'function', like forced analogies with contemporary IR theory, can be contrasted with a quite different understanding of imagination, in which escapism is not extraneous to, but instead a principal part of, the case for cultural analysis. The point is not just that the 'realism' of SF is discernible only in retrospect. More, genre in its surface irreality yields a map of collective experience and opinion, a real expression even if the futures anticipated are never realised. The fears and anxieties are sense data, conveyed to an audience and put into cultural circulation, but not for that reason inputs for a computational model of future politics.

Such speculation and diagnosis are to be found also in political theory. An all too brief history of utopia clarifies the stakes. The term utopia (meaning no-place, distinguishable from eutopia, the good place, as well as dystopia, the bad place) has a heritage as long as western political theory; which is to say, as old as Plato. But the flourishing of interest in ideal societies is conventionally traced to 1516 and Sir Thomas More, counted also as a forefather of science fiction (e.g. Amis 2012, 14). Written while More was an acting diplomat, and when he was contemplating a position as a privy counsellor to King Henry VIII, Utopia betrays a deep affinity not just with international political theory, but with international political

\footnotetext{
12 This view is attributed to Isaac Asimov (Aldiss 2013, 28).

13 See 'Nightcap: Conversations on the Arts and Letters', Alpha Repertory Television Service, with Studs Terkel, Calvin Trillin, Isaac Asimov, Gene Wolfe, 1982, available at: https://www.youtube.com/watch?v=RZvcKB9vQO0
} 
practice, and was understood at the time as a guide to virtue and statesmanship (see Bruce 2008; Hallberg 2012). Where More emphasised the political organisation of the commonwealth, a century later Francis Bacon proselytised technological mastery in his own unfinished utopian novel New Atlantis, leading the cultural theorist Raymond Williams to argue that the history of modern socialist thought could be profitably defined in terms of the contest between, and fusion of, the two tendencies (1978, 206-210; cf. Frye 1965).

Questions of literary realism and utopia parallel those of political realism and utopianism: the former are at the mechanical heart of speculative fiction; the latter lace the history and historiography of International Relations. As is well known, the distinction between 'utopia' and 'reality' animated E.H. Carr's The Twenty Years Crisis, a seminal text claimed by political realism, and the two concepts have been subject to debate and revision ever since (Carr 2001; Booth 1991; Onuf 1994; Brincat 2009; cf. Ashworth 2006). 'Utopian' has served as a blanket term of opprobrium, but also been recognised as a necessary element of international thought. A wide swathe of international relations scholarship, Carr's included, may be read as pursuing utopian ideals, if tempered in various ways. In the field of normative theory, idealised settings partake of this utopian legacy: John Rawls' veil of ignorance, for one, might easily be mistaken as a device lifted wholesale from science fiction, a fantasy that nevertheless holds out the promise of a revised reality (see Brown 2002).

The intimacy of political and fantastical thought is further discernible in IR's supposed founding period. To take but one example, in 1933, H. G. Wells published The Shape of Things to Come, an SF novel reporting the prophetic visions of Dr Philip Raven, a League of Nations intellectual who inexplicably dreams the future. In it, Wells presented an incipient diagnosis of liberal internationalism's failure, an anticipation of World War II (sparked in an alternate 1940 by the murder of a Jewish traveller in Danzig), and a manifesto for a world state. The Shape of Things to Come is at once a historical document through which we can understand the Fabian attitude, a reflection of the social anxieties of the period (the passages on the use of poison gas in warfare, imperial overstretch and international finance are particularly revealing (Wells $2005,108,126,171,247)$ ), and a piece of political theory in its 
own right. ${ }^{14}$ After all, the League of Nations was a utopia to some, until it wasn't, soured into dystopia and embarrassment. That Wells also wrote explicitly on matters of politics, and that several of his other fictions take a prophetic tone, only serves to indicate the porous barriers of genre.

Utopias may indeed be divided into non-fictional and fictional types: the former including works of political philosophy, instructions to princes and other maps of 'intentional societies' (Sargent 1994, 12); the latter covering various myths, fairy-tales and the like. In this second of its lineages, utopianism can be grasped as a common feature of thinking extending far beyond the realms of organised politics, as what has been called 'social dreaming'. ${ }^{15}$ And yet IR treatments of utopia and dystopia tend to be circumspect, scrutinising those terms only insofar as they are invoked in canonical political theory (Onuf 1994) or by formal political actors (Callahan 2004). That is, as a property of social engineering, systematic and comprehensive. On this account, searching for traces of utopia is a method for understanding the motives of the speaker, and can be used as a metric against which to judge the rationality and ambition of their politics. The objective is, then, to ascertain which are the utopian claims about the international system, rather than to see utopian dreams of all sorts as themselves part of international theorising.

Against the notion of 'utopia as a blueprint' (Brincat 2009, 582), to insist on the existence of a utopian dreamworld beyond formal political discourse is to consciously dissolve the borderland between political science and literary criticism. Moreover, far from belonging only to modern, crude mass culture, utopias should be understood as deeply implicated in both classical and contemporary political thought (Shklar 1965; cf. Miéville 2016). All utopian speculative fictions in More's wake were critical of the institutions of their time, often supplemented by a programme for the redemption of society (Sargent 1994), but sometimes a condemnation of the existing order alone (Shklar 1965, 369-372). On Northrop

\footnotetext{
${ }^{14}$ See, relatedly, H. Bruce Franklin's history of superweapon ideology. SF predictions of nuclear weapons came as early as 1908 in Hollis Godfrey's The Man Who Ended War, a title obviously foreshadowing ideas of the nuclear peace, even if the plot involves a more ludicrous process of coerced disarmament (Franklin 1988, 50-52).

15 But not for that reason necessarily radical, since "for some people at any time dream of something basically familiar" (Sargent 1994, 3).
} 
Frye's (1965) account, both the social contract and utopia - the one expressing the origins of society, the other its telos - depend on a sense of the fantastical, likewise found in myth. Comments Samuel R. Delany elsewhere: "Virtually all the classics of speculative fiction are mystical" (1977, 34; cf. Atwood 2011, 38-65). An intellectual history of the political within the fantastical requires a certain intricateness, for the meaning of social criticism depends on the reigning norms of the society in question, varied by time and space. Yet the use of extrapolation and speculation in political thought encompasses figures as obviously canonical as Plato and More, Bacon and Thomas Hobbes, Jean-Jacques Rousseau, Charles Fourier and Karl Marx, before finding voice in the post-war utopian satires of Orwell and Huxley. ${ }^{16} \mathrm{~A}$ boundary that puts Hobbes' speculative thought within the domain of political theory proper, but which relegates More, Shelley or Wells to literary studies is liable to artificially circumscribe the field and to exclude from consideration much of the material with which political thought proceeds.

The conventional approach to utopia serves as a microcosm of the larger argument presented here. IR's analytic is predisposed towards concrete, pragmatic, explicitly political, realisable visions and against the wishful, fragmented, surreal, and excessively abstract kind: disciplined against undisciplined dreaming (Levitas 1990; on discipline, see Weber 1999). This gives rise to a tension between restrictive and capacious attitudes to the selection of materials, and to differing methodological approaches for the decoding of signs. Of course, IR work on aesthetics already engages extensively with mass culture. And yet many who would take a broad view of what counts as analysable material nevertheless retain a disciplinary sensibility, in the sense of organising the relation between fiction and worldly politics in a highly structured, arguably (and I will argue) reified, manner. So at the same time that IR's "scholar-fans" (Henne and Nexon 2013) have recognised the constitutive relation between culture and politics, they have also muted the distinctive characteristics of culture as dreaming.

16 This list contains no female political theorists, because they are not conventionally seen as canonical, present as they were. The cases of Margaret Cavendish, philosopher, scientist and author of the utopian The Blazing World (1666) and Mary Shelley, not coincidentally daughter of two political theorists, are perhaps instructive. 


\section{The Marilyn Monroe Doctrine}

International politics can be traced in speculative fictions; there is equally something fantastical at work in everyday, and putatively realistic, discussions of international relations. ${ }^{17}$ Politics assumes for itself a creative licence about the past as much as the future, not least because how the past is imagined determines the legitimacy of present arrangements. Motifs travel in both directions, allowing us to apprehend real politics and realpolitik in the speculative and also to see in worldly political speech the long shadow of the fantastical, an unrealpolitik. Utopia and dystopia are internal to politics as such, including the utopias of colonialism, world government, free markets and humanitarianism (Miéville 2015). As has been so incisively set out by Barry Hindess (2007), ideas of past and future are displaced spatially in the discourse of progress. There are places and cultures that exist in our present that are treated as if they were vestiges of the past. Although none would claim that the peoples of the 'Third World' literally exist in a different time-stream, this is the imaginative effect of characterising the political institutions and cultural attitudes of some nation-states as 'behind' those of others, in dire need of 'catching up' with modernity. Without a theory of contemporaneous unevenness, developmental discourse becomes an SF tale of alternate universes. It implies a truly weird, even uncanny, view of time and space. 'Uncanny' originally meant 'dangerous' and later that which was not homely or native (Jackson, 1981, 64-65; cf. Miéville 2012). Political theory as such rests on diverse senses of worldly time (Hutchings 2008, 12-20), and the clash between historical tempos within it can have the same disorientating effect as the time travel story.

Progressivist conceptions of international politics imply nothing less than the futurology of an imagined past: an escape velocity based on stylised interactions like the social contract. Alertness to the dynamics of SF is an aid in the interpretation of such histories. The 'foreign' and the 'alien' are after all cognate terms, most obviously in their interchangeability within Anglo-American legislative discourse (the 1905 Alien Act in the UK, the 1798 Alien and

17 Wendt and Duvall (2008) explore the salience of science fictions in a related, but importantly different, sense by showing how the branding of an issue in SF terms can act to make the ontological boundaries of modern rule less visible. 
Seditions Act in the US) (see also Lipschutz 2003, 80). The etymology is not without relevance for an analysis of identity-making. The conceptual history is moreover gendered and sexed as well as raced: "Aliens are by definition queers", as Istvan Csicsery-Ronay had it (2007, 14, cf. de Laurentis 2003). It was Martin Wight who, in alluding to the drama of 'natural hostility', remarked that "one of the charms of international relations [was] that more than any of the social sciences it approximates to science fiction" $(1991,50)$. The fearful conceptualisation of difference does not, to be sure, belong exclusively to SF or to IR. For while the encounter with the Other perhaps reaches its stylised height in certain SF examples, the threat of foreign bodies is mobile, recurrent, and mutating. There are aliens to be found in The Merchant of Venice, and in Moby Dick too. ${ }^{18}$

In this sense, the analysis of SF can be justified on similar grounds to that of popular culture at large, of which it partakes and to which it contributes. Because re-presentations partly constitute the political sphere, they are properly objects for political analysis, including where they eschew the conventions of literary realism. ${ }^{19}$ In the hands of the screen-writer the essence of a political idea may be communicated with greater force and economy than found in the legislative chamber or the academic treatise. On this view, political discourse paradoxically thrives most outside of its own formal bounds, and is all the more effective when taken as a triviality. Certain political realities can only be approached indirectly, at an angle, perceived askew. ${ }^{20}$ It is as if the doctrine of great power exceptionalism was best conveyed by Marilyn Monroe in the The Prince and the Showgirl, where Monroe's character at one point proclaims, "I'm an American citizen. Nobody can do anything to me!" (see May, 2011). This is a vision of mass culture as translation, cognisant that most citizens will never speak the language being translated with sufficient mastery to do away with the translator.

Some speculative fictions - such as those of a feminist, black or socialist bent - are most easily read for political content for the obvious reason that feminism, anti-racism and socialism are

\footnotetext{
18 See the discussion in Csicseary-Ronay 2007. The reference to Shakespeare is borrowed from him (Ibid., 19).

19 On presentation and re-presentation, see Neumann 2001.

${ }^{20}$ A favourite refrain of Slavoj Žižek (e.g. 1989).
} 
political movements. ${ }^{21}$ Radical SF is written from a perspective not well served by mainstream political theory, and is for an audience traditionally excluded by it. If popular culture establishes a moral cartography or partakes in moral education, then a critical reading will uncover the moral structure of a given society or social formation. Scholars may then use pop culture artefacts to gauge national anxieties (Nexon 2007; Neumann and Nexon 2006; Sontag 1965; Disch 1998). Certainly, the politics of SF has been interpreted as dangerous by state censors: in one recent example, China's State Administration for Radio, Film and Television issued an edict against the depiction of time travel (Barboza 2011). As Theodor Adorno knew, "the strongest argument in the arsenal of apologists for cinema is the crudest, its mass consumption" (2005, 203).

Consider two further illustrations (there are many more) separated by decades and continents. By common consent, the first interracial kiss on American television occurred during an episode of the popular science fiction series Star Trek in November of $1968 .{ }^{22}$ Although the scene is today taken as emblematic of the civil rights movement, in the plot Captain Kirk and Lieutenant Uhura are moved not by passion but by telekinesis, their bodies compelled for the amusement of extraterrestrial acolytes of Plato (the episode is called 'Plato's Stepchildren'). In spite of reservations about her character Uhura, Nichelle Nichols was encouraged to remain on the show by Martin Luther King Jr., who saw her as a powerful symbol in the struggle against white supremacy (NPR 2011). In an apparently unrelated episode, in May of 2014, a military coup took place in Thailand. In addition to dissolving democratic institutions, the new junta greatly restricted freedom of assembly and expression. In response, protestors adopted the distinctive three-finger salute from the popular science fiction film (and previously book) series The Hunger Games at their rallies. The gesture was outlawed and students arrested for raising it, leading some theatres to cancel showings of The Hunger Games: Mockingjay Part 1 (Mydans 2014).

21 'Black SF' is a flawed term, but one that enjoys wide use. 'Afro-futurism', whilst more attractive, refers to a more specific set of narratives. See Bould 2007, cf. Name 2008.

22 'Interracial' here means between a white man and a black woman, since kisses between white and non-white characters had previously been televised. And there were clearly kisses on film before 1968, as well as kisses shown in territories other than the USA. There is even debate about whether a kiss is really shown at all, the camera angle obscuring our view of the lips. 
In both moments the speculative fiction is symptomatic. In the Thai case, SF provided a vocabulary of protest organically linked to the protesters' own, and interchangeable for the purposes of signalling resistance. As for the Kirk-Uhura embrace, genre is usually taken as crucial to its radical impact on sexual mores. An interracial kiss would have been unconscionable in a show set in the actual United States of the time. On this view, only in a speculative future that has as its condition the resolution of all collective human conflict (both material scarcity and war have been abolished on earth) could such an encounter be believed; only within the speculative bounds that suspend existing conditions could the concrete struggle for racial equality be represented to a mass audience, the taboo broken. ${ }^{23} \mathrm{SF}$ is thus commonly understood as a special case of pop cultural artefact - having the character of what Darko Suvin, in the most influential critical framework to date, termed cognitive estrangement: the narrative combination of rational extrapolation from the conditions of the present (cognition) into spaces that unsettle, confound and delight in comparison to the quotidian (estrangement) (Suvin 1988, 35-38; cf. Beaumont 2009).

\section{Twice Upon A Time}

Speculative fiction traffics in the strange, because to think the future is also to think strangely. ${ }^{24} \mathrm{SF}$ dramatises elements of the political moment, extending, elaborating, exaggerating, and formalising them. Cognitive estrangement proceeds by both a diachronic mode - reading SF for warnings or hopes from the near future, as a pseudo-realistic historical narrative - and a synchronic one - where imaginary elements are interpreted as mirrors of present events. Dystopias and post-apocalyptic narrative are most susceptible to diachronic readings; synchronic ones tend to allegory (Hollinger 1987). The discussion of torture in Battlestar Galactica, to take one recent illustration, has been interpreted as commentary on US policies in the war on terror as they exist contemporaneously, rather than as a caution on what might occur if certain tendencies were to persist (Buzan 2010).

\footnotetext{
23 The taboo in question being that of representing inter-racial intimacy, but clearly connected with actual social restrictions. It was only in 1967 - one year before the broadcast of 'Plato's Stepchildren' - that the Supreme Court found miscegenation laws to be unconstitutional in Loving $v$. Virginia.

24 On Suvin's subsequent alteration of the boundary between SF and fantasy, see Miéville 2009.
} 
SF/IR has largely dedicated itself to demonstrating how a given cultural artefact corresponds to global politics, a necessarily synchronic approach emphasising the cognitive side of Suvin's definition. As Iver Neumann and Daniel Nexon argue in their volume on the fantasy septology Harry Potter (2006), IR work on pop culture commonly treats it as a mirror for analogy and exploration. The tendency is to read established actors and categories across into a fantastical realm the better to use the fantastical to illuminate world politics in turn. Hence claims of the sort that Game of Thrones "force[s] the audience to confront the violent reality of feudal gender relations" (Carpenter 2012, see also Clapton and Shepherd 2016); that Blade Runner is "a reflection of transformations already taking place in the political economy of the United States" (Lipschutz 2003, 88); or that rivalries in Star Trek mirror those between 20th century empires (Weldes 1999; Buzan 2010; cf. Inayatullah 2003; Whitehall 2003; and on early SF's indebtedness to imperial and racial anxiety Seed 2010; Bady 2011; Franklin 1988). William Faulkner proclaimed that the past is never dead, it's not even past. Similarly, for many an interpretation of SF, the future is not coming, it's not even the future. ${ }^{25}$

The tendency is most evident in the case of Dan Drezner's immensely popular work on zombies (2011). ${ }^{26}$ Despite a single footnote on the zombie as metaphor, and a small gesture towards them as expressions of capitalist consumerism, the main accomplishment of Theories of International Politics and Zombies is instead to illustrate mainstream theories, taken as 'paradigms'. Questions of cultural theory, the cosmologies of race and gender in the zombie terror, the origins of the zombie scenario in the international politics of slavery (its historical function and conditions), and the meaning of our contemporary fascination are all eschewed in favour of levity. The scholarly reception of Drezner's guide has been exuberant, largely due to its serviceability as classroom prop. This success presages a reduction of cultural artefacts to summaries of IR theory (e.g. Sterling-Folker and Folker 2006 on the state). This approach - which I term descriptive-analogical - has come under increased scrutiny of late (Hannah and Wilkinson 2014; Grayson 2015; Carpenter 2016), but remains widespread. In

\footnotetext{
${ }^{25}$ A similar sentiment, attributed to William Gibson, is that the future is already here, but it's not evenly distributed.

26

It may be objected that the recent zombie craze in IR has nothing to do with speculative fiction, but belongs properly to horror. But Kingsley Amis was able to observe, as long ago as 1960, that "between them science fiction and fantasy have managed to gobble up most of what was left of the horror story without much injury" $(2012,108)$, a situation that persists, and has only grown with the 'explanation' zombies in pseudo-scientific terms (the outbreak of a virus and suchlike).
} 
it, other worlds serve as mental pictures that aid or excite thought. Descriptive analogies thus recruit the speculative and the fantastical to make sense of world politics not because those narratives trouble or undermine or reimagine it, but because they replicate it in a way that is taken to be more easily digestible than speaking directly. The strategy reflects the relative insecurity of pop-cultural analysis: by showing that there are correspondences between units of international politics and the agencies of an SF universe, the relevance of SF is made more evident to IR sceptics, at least on the surface of things. Fantastical worlds then serve as models miniature of global power - putting the political science into science fiction - rather than as acts of vibrant imagination on their own terms.

For self-consciously critical scholarship, description is supplemented by a somewhat different orientation, one that leverages cognitive estrangement to indicate the political limits of the international system and current IR theory. Analogy remains important, but the emphasis is much less on contemporary geopolitical situations or textbook theories. It is instead variously argued that pop culture "reproduces" things (power relations, prejudices, myths) (e.g. Shepherd 2013, 122); that it "naturalises" existing histories and power relations in a fantastical register (Weldes 1999, 127); that it expresses collective angst (Towns and Rumelili 2006); or is otherwise "illuminative" of contemporary politics (Maisonville 2013; cf. Sterling-Folker and Folker 2006, 103; Crawford 2003, 197). SF motifs may not act as a direct causal influence on world events, but nevertheless "provide one layer in the complex continuum" producing feelings towards others (Grayson, Davies and Philpott 2009, 156). Some argue that "fictional universes serve as silent, sub-textual pillars of the real" (Kiersey and Neumann 2013, 5). More strongly, SF has been credited with making "ethical sophistication [possible] by displacing events" (Crane-Seeber 2013, 184) or in part contributing to the very "constitution of a world in which hierarchy, intervention and militarism are taken for granted" (Weldes 1999, 127, emphasis added), the world in question again being ours. Drezner himself is both more cautious and more open: pop culture simply "often provides a window into the subliminal or unstated fears of citizens" (2011, 4; also Jackson and Nexon 2003, 144; cf. Nama 2008, 8, 15). 
These claims are diverse, and each could be unpacked in its particularity. But all also share a certain presupposition, namely that the text of speculative fictions increases our understanding of the world we inhabit and which we take as real, mundane, and actionable. The understanding we gain is relatively precise: the correspondences are direct, and meaningful, which is why articles on SF artefacts can take their place alongside more traditional historical or sociological readings of world politics. This perspective is also a critique, a way of not just mirroring, but transforming: the first step in formulating change in the non-speculative, actual world. Every science fiction story is for someone, and for some purpose. SF/IR is then positioned to track the transition from alterity to alternatives. As has already been argued in literary theory, through its peculiar techniques SF yields a view which is otherwise "inaccessible directly... Elaborate strategies of indirection are therefore necessary if we are to break through our monadic insulation and to 'experience', for some first and real time, this 'present', which is after all we have" (Jameson 2005, 287, emphasis in original). Thus can the analysis of SF be seen to operate in a manner not dissimilar to broader currents of critical theory or post-structuralism (Crawford 2003, 209). A looking awry that also implies a correction of vision.

That SF might reveal political power is indispensable to the case for its inclusion in IR, and is implied by the discussion of fictions as a hinterland to political theory above. And yet the emphasis on parallels and analogy also threatens to deprive SF of its estranged character. Even where texts are acknowledged as in principle open to several readings, the requirements of the analogical method of interpretation privileges an already-given series of one-to-one correspondences. That subjective judgements are involved is not in itself damning. But analogy - showing that a fragment of SF has as its twin some aspect of IR - gives the illusion of a robust empirical examination that in truth sets to one side the same imaginative expanse it otherwise acknowledges. This is not to celebrate a plurality of interpretation for its own sake, but to argue for a view of the interactions of text and audience that takes the rivalry of meaning as inescapable.

A reductionism haunts $\mathrm{SF} / \mathrm{IR}$, but also a vagueness in establishing the grounds on which correspondences are drawn. Thematic similarities have been identified between the 
conceptions of evil in Christianity, fantasy and political realism (Hall 2006); between liberal globalisation discourse and the novels of Isaac Asimov (Weldes 2001); between the character of Sméagol/Gollum in The Lord of the Rings as the postcolonial split subject (Ruane and James 2012); and between Mormon theology and Battlestar Galactica (Neumann 2013), amongst others. The salience of these readings depends heavily on finding the echoes of politics within cultural artefacts, but the themes uncovered can be abstract and indistinct, for example in observing that claims for the benevolent impact of technology feature in both the text studied and the real world (Weldes 2001; cf. Disch 1998). Many such themes - justice, order, fear, difference, change, progress, violence, power, identity - are ubiquitous in the long story of human experience. The insistence on a mirror effect is needed even where the SF universe does not resemble our own, as in the contrast between widespread nuclear weapons use in Battlestar Galactica and the nuclear taboo operative in contemporary world politics (Fey, Poppe and Rauch 2016). Regardless of whether these individual readings are persuasive, they reveal frustratingly little about audience responses and behaviours, about how culture may shifts collective opinion or be used to manipulate it, about the significance of fictions in broader ideological struggles, about the validity of any given theoretical explanation (realist, liberal, etc.) that the artefact may mirror, or about the proper ethical response to either the artefact in question or the piece of theory/politics of which it is said to be the simulacrum.

For example, in a recent intervention, Christina Rowley and Jutta Weldes have argued that the seven components of the 'international security studies myth' (referring to Buzan and Hansen 2009) are directly mirrored by narrative developments in the television show Buffy the Vampire Slayer. In short, just as security studies has moved from a simple narrative to a plural understanding of insecurity, and now recognises a diversity of actors and concepts, so too did the characters in Buffy successively challenge boundaries between domestic and international, open up identities, and progress beyond militaristic solutions. On this account, the two narratives (security studies and Buffy) work in parallel: e.g. "[t]hreats are decisively dealt with by Buffy through the use of force; just as in realism, relative force is what matters" (2012, 518). For Rowley and Weldes, this reading indicates the 'everyday' character of security discourse, and has "significant implications for how and what we research" (Ibid., 
526). Leaving to one side the question of whether this particular series is a useful example of folk security discourse, the correspondences are at points vague in the extreme, for how many cultural narratives are not in some way about identity and insecurity? Without reference to audience survey data, inter-textual analysis of Buffy within the genre history of horror and fantasy, or some theoretical exposition of just how the elements of narrative convey such clear messages about danger and community, the comparison is mutually reductive, denuding both 'sides' of their style and purpose. Excavating an analogical series then greatly constrains both the history of security studies and Buffy as cultural artefact. ${ }^{27}$

The tendency to descriptive forcing is less an error of interpretations than a chronic tension of parallel reading. Whenever systematic analogies are drawn there is always the peril of what has elsewhere been called simplistic politicisation (Hozic 2003, 134). The cultural artefact becomes over-burdened with inferences about its meaning - a meaning which must be more or less singular if it is to 'mirror', 'explain', or 'reflect' concrete world politics. Whilst superficially receptive to the special status of culture, simplified analogical readings necessarily constrains imaginative politics. They seek to grasp indirect effects through direct readings, and so are easily seduced by the observance of some correspondence. The quest for analogy frustrates the multiplicity of cultural artefacts. Andrei Tarkovsky, exasperated by theories of what the magical 'Zone' truly meant in his film Stalker, replied: "The Zone does not symbolise anything!" (Hozic 2003, 128). The creator doth protest too much, no doubt, but the rebuke stands as a plea for irreality.

In an important sense, the distinction between disciplined and undisciplined dreaming echoes Roland Bleiker's early warning of the gap between a mimetic and aesthetic approach to representations, in which the former asserts a pre-existing reality in an attempt to ground the representation in something else, whilst the latter embraces direct experience of the representation-as-such (Bleiker 2001). The contrast between mimesis and aesthetics was intended to resist the reduction of the representation to what it represented. Insofar as pop

27 In something of a contrast, Molloy's (2003) reading of order in sovereignty through Buffy identifies a series of resonances, exploring possible messages, without ever rising to the claim of either a mirror of or a lesson for worldly politics. 
cultural IR accesses political reality through SF artefacts - to thereby critique a structure that lurks begun the surface of story - it is indebted to a view of cultural representation as a kind of copy. ${ }^{28}$ Against this implicit theory, contrast Paul Ricouer (1979). Rather than defining fiction as akin to mental images that correspond with aspects of reality, Ricouer sees it as an unreal mechanism that helps produce (heighten, concentrate, selectively illuminate) the experience of reality. A fiction is not a replica. A fiction has no given model; it does not refer like a copy, but is a novel combination without a prior original. The correspondence that exists in a photograph has an antecedent: the photograph refers to something real, but absent (the person or object in the photograph). Fiction, however, is asymmetrical in its relation to reality, and thus unreal. It is the lack of symmetry which must be the starting point for a phenomenology of fiction (Ibid., 126). In no way does this imply that fiction exists on an isolated, disinfected plane, devoid of connections to political life or concurrent events. Instead, this is "the paradox of fiction: Because it has no previous reference, it may refer in a productive way to reality, and even increase reality" (Ibid., 127, emphasis original).

Contrary to common procedure, the elaboration of a mirror image between fantastical worlds and international politics does not in itself establish the relevance of the analysis as either cultural criticism or IR scholarship. As Charli Carpenter has recently argued with great persuasiveness (2016, 55-57), claims about the constitutive and causal impact of SF and pop culture require clearer evidence than has usually been forthcoming. Whether an SF piece indeed reveals the truth of an era, as Kinglsey Amis once claimed $(2012,42)$, is in need of concrete demonstration. Even where a conscious analogical motive can be shown - it is for example said that Gene Roddenberry intended for the Klingons in Star Trek to represent the USSR (Dittmer 2010, xi) - the received meaning of a cultural artefact will exceed it. The elevation of analogies in IR studies of SF, whether descriptive or critical, has left the promise of the genre as a reservoir of political aesthetics only partially fulfilled. In some cases, the impetus to teach or illustrate politics through SF has involved drastic simplification. Fantastical or speculative time is made to correspond to, and in part to contribute to, the

${ }^{28}$ For all the insistence on the aesthetic as a distinct encounter, Bleiker's appeal to 'forget IR' is nevertheless made on the same grounds as an endorsement of aesthetics for the insights they afford into world politics as such, presumably then recuperable for IR. 
political epoch we currently inhabit, a somewhat distorted but still recognisable version of ourselves, a stranger returning, its face the uncanny valley, as if IR had assembled its own replicant (cf. Weber 1999). For SF to serve as futurology, an easy parallel for international society, or an ideological reinforcement of global order, the rich contradictions of its many narratives must be suspended, in a move redolent of the protagonist in Russell Hoban's fantastical novel Linger Awhile, who revives dead movie stars by placing film of them in a thoroughly implausible reviving fluid, a literal 'suspension of disbelief'.

\section{$\underline{\text { These Violent Nets of Wonder }}^{29}$}

It might be argued that the preference for decoding SF narratives to uncover relations of power and dominance tallies with a disposition in SF literary criticism to accomplish the same. Left-leaning authors like Joanna Russ have argued that SF is didactic: it teaches lessons (1975). The reader or critic may then identity the political disquisition in SF artefacts, even seek out the extra-terrestrial scene precisely to examine political questions. The most commonly offered case is The Dispossessed, Ursula K. Le Guin's 1974 genre classic, readable as Cold War parable and once described as "the crowning novel of the US 'leftist' trend" in SF (Suvin 1988, 55; cf. Freedman 1987, 192-194; Williams 1978, 212-214; in IR see Crawford 2003; Jackson 2013). The depiction of gender in Le Guin's The Left Hand of Darkness - where the inhabitants of Gethen have no fixed sexual identity, adopting 'male' or 'female' characteristics during a time specially set aside for reproduction and known as 'kemmer' - has likewise won praise. The less widely-read The Word For World Is Forest, set on the planetary colony of 'New Tahiti' and exploring the revolt of the indigenous rural population against 'yumen' overlords, served as a more-or-less direct critique of the Vietnam war (Franklin 1990). Many readers find Le Guin exhilarating as an architect of radical politics, even as she has now and again sought to disrupt such readings (Le Guin 1989). Her fantastical worlds have an obviously political atmosphere (it is telling that the functioning of the kemmer period in The Left Hand of Darkness is relayed through the dispatches of a diplomat). Le Guin's reception indicates not only that political theory is indeed consumed through SF, but also implies that direct analogical readings are easily accomplished. Her

29 See Delany 1977, 34. 
works, we might say, are parables. Hence the complaint put most harshly by her fellow SF antagonist Thomas Disch: "One does not read Le Guin for fun" $(1998,125){ }^{30}$

In chastising American SF for its conservatism, Le Guin once sardonically appealed for a new SF that would express "such deeply radical, futuristic concepts as Liberty, Equality, and Fraternity" (Le Guin 1975, 210). The quip revealed a truth. Rights of Man is also a work of speculative fiction, a grand what-if, its claims on the political future now in gestation for longer than most predictions of moon travel or genetic engineering. The claim for the special powers of SF may further dissipate if The Dispossessed is read side by side with a text like Orwell's Homage to Catalonia. In a non-speculative register, it too surely offers a critique of the present, a vision of an alternative future, and a sense of rich human flourishing (as compared to dry political dogmatism).

We might then remake the distinctions already encountered - disciplined versus undisciplined dreaming; cognition against/with estrangement; mimetic versus aesthetic approaches to representation - by distinguishing between the identifiable political content of a cultural work and the imaginative grip it exerts upon an audience. This is not to say that a 'fictive' element can be easily separated out from a properly 'political' one in all SF, nor to attribute political effects to political speech alone. The parallels have to be unearthed: that labour is called criticism. But criticism need not insist on symmetry, for to continually 'read' the speculative for discrete political content, for coded messages about ourselves sent from a future we are fantasising, is also to foreclose part of the experience of speculation, resolving all too easily its cacophony of dream-wishes.

The political meaning of SF can be differentiated in terms of two sensibilities, operating at different frequencies of sensation and thought. Both are ways in which SF might be political, and ways that it might be read. The first is as political expression. The speculative is, as we so often stress, not just a thought-experiment of what might be, but a refection of what we

30 Samuel R. Delany has offered a related critique of Le Guin, pointing to the didactic quality of her writing and some less-than-radical ideas on sexuality and family (Delany 1977, 272-283; Le Guin 1989, 169-171). It is also worth noting that Fredric Jameson attributes Le Guin's success in political re-imagining precisely to her innovation of a literary technique that he calls "world-reduction" $(2005,270)$. 
are experiencing, and always already saturated with contemporary political dissatisfactions. Thus the distinctive political aura of a figure like Philip K. Dick, whose work offers the paranoia of pulp noir, travelling in playfulness or dread with motifs of surveillance, selfdeception and freedom. The second sensibility is that of the political programme. References to a re-imagining of politics through SF indicate this function, as if a novel incites an awareness in its readership translatable into an alternative future that can readily be made manifest. Programmatic SF thrives on the fantastical fable as a concrete political intervention. SF works of this sort can come to be seen as political documents in their own right, as when Orwell's Nineteen Eighty-Four is thought to have somehow forestalled a loss of liberty, and its consumption with Animal Farm today taken a ritual prophylactic against totalitarianism.

Thinking of SF as politically expressive does not allow for much in the way of direct descriptive analogy, but resonances between invented and real worlds is are recognisable still, are in truth crucial to the social meaning of a work. That is, when a work garners attention and popularity, intellectual curiosity about its significance is deserved, but need not take the form of mapping any singular meaning for IR's analytical or pedagogical purposes. Radical extrapolations might serve as manifestos, but can equally thrill with their sheer inventiveness. Expressivity - the sensation and immediate pleasure - remains political, a structure of feeling, but at a different cadence than is implied by substituting in international institutions for their make-believe counter-parts. It is synchronic, but not in fixed parallel.

At a certain level, politics in this mode becomes indistinguishable from play. Samuel Delany writes that SF is less "predictive" than "incantatory", meaning that it names non-existent things and then goes about "investing them with reality" and value $(1977,126)$. The expressive form of SF is, then, not simply assimilable into its programmatic one. Readers may feel the politics in SF, and take it as self-evident that a pop cultural artefact means something politically, and even find the meaning quite specific in real world terms (beware environmental degradation, resist religious power, make technology serve humanity, and so forth) (see also Shaviro 2016). Yet even without investigating aesthetic styles that resist the literal, such as magical realism or the 'new weird', reducing the expressivity of a cultural artefact to a given political programme or analogy forecloses its meaning in advance. In 
noting that SF is not simply fiction, there is a forgetting of the ways in which it remains so. In the act of scholarly interpretation, SF as a technique of understanding subsumes SF as a kind of wonder.

The speculative fictions that have proved of greatest interest to IR are part of the hinterland of political theory, as already defined. If daring acts of imagination, they cannot possibly correspond to textbook accounts of world politics. And yet they convey political discourse. To seize too readily on the political implications of speculative writing is to swerve "that peculiar, unsettling, vaguely supernatural sensation" (Miéville 2012, 378) that comes with true estrangement. ${ }^{31}$ Proper monsters do not brook resolution or party allegiance. The programmatic character of politics - its specificity and antagonism - cannot be imported wholesale via fictional narrative. This may seem obvious, and yet analogical approaches suggest as much where they treat SF artefacts as betraying a worldly truth. The fiction of a political speech given to the United Federation of Planets is received differently to an actual speech before the earthly United Nations. The former is still an example of political rhetoric, informing the meaning of other iterations of the same (cf. Dittmer 2010, x), yet is not bound by the same subjunctivity. Far from being flattened into an undifferentiated plane of 'narrative', the differences in the constraints of realist and speculative political speech are precisely what makes a fantastical setting amenable to novel interpretation and insight. In the difference lies the whole value of genre.

The expressive function in speculative fiction is world-revealing; the programmatic one world-making. Revelation in the recognition and articulation of a condition, a quality of experience; making as the plurality of projects of the future, speculation in the broadest sense. Where analogy and prediction might be clear enough in Wells' The Shape of Things to Come (that warning-wish of liberal internationalism) or James Cameron's Avatar (readily grasped as a parable of counter-insurgency), the political lessons are perhaps harder to discern in as

31 China Miéville is writing here of the uncanny and its relation to monsters. Miéville himself is conspicuously absent from most IR writing on SF, which is surprising given that he is a recipient of the Hugo and Arthur C. Clarke awards (three times for the latter), an incisive critic of the genre, and holder of a $\mathrm{PhD}$ in International Relations. 
widely-consumed an artefact as Ridley Scott's Alien. ${ }^{32}$ On Barbara Creed's compelling reading in The Monstrous Feminine (1993), Alien conveys the history of the fear of the archaic mother. Its nightmare is the mutation of feminine life force, the audience's revulsion achieved through transformations of 'the primal scene' of heterosexual reproduction - the alien oral impregnation, the face-hugger's proboscis-pudenda as a penis in the throat (an otherworldly rape), men laid out in a parody of birth, the viscosity of eggs as a foreboding of organs in revolt.

To concur with Creed's interpretation is to be shown something about the gender politics of the world and their expression in culture. But that is not to say that Alien offers a political parable, still less that the various creatures and events 'stand in' for the world of politics and are readable through analogical correspondences. Rather it is the act of cultural criticism and the consumption of criticism - which guarantees the effect it purports to describe. ${ }^{33}$ Interpretive reading creates meaning, and does not merely reveal it. Against the quip credited to Ernest Hemingway - that the critic is one who watches the battle from a hilltop before coming down to shoot the survivors, a critic, at their best, is one who reanimates corpses from the battlefield, and makes them dance anew. The unmediated experience of the film transmits something to its audience, and when successful leaves them with a sense of unease, something out of place. The interpretation of the unease follows, cognition on the heels of estrangement. Where preference is given to text alone over context, inter-text, or extra-text, pop-cultural scholarship is limited in its ability to interpret the varieties of feeling that a work excites (and of course, excitement is sometimes killed in the act of interpretation, which then becomes a post-mortem). In the case of Creed's reading of Alien, interpretation implies a conceptual distinction between the source of audience disgust (which may well rely on half-perceived taboos) from the politicised account thereof. Thus Alien both expresses and projects the sometime hatred of the feminine onto a screen populated by monsters, but in ways that require active translation and sense-making.

32 Avatar is also one of the highest grossing movies of all time. Understood as a defence of local culture and sovereignty against military superpowers, it has enjoyed a wider circulation than any other single piece of anti-war propaganda in history (see also Der Derian 2010).

33 Space limitations prevent an exploration of other exceptional close readings, but see Miller 1976; Jeffords 1989; Jameson 2005. From IR, two recent examples are Maisonville 2013 and Wilcox 2013. 
The traction of the expressive in SF is not randomly distributed. Sensations of wonder and unease are conditioned by the historical moment, which is itself partly constructed from prior acts of imagination. The important point is that an interpreter of the spectrum of responses and ideological resonances in any given work seeks out not just parables of the world political, but also evidence of subversion and juxtaposition, friction, a collision of perspectives, the rhetorical interplay of a text and some other work to which it is paying tribute, playfulness, satire, wilful parody, and more besides, not to mention the arbitrary defects introduced by editors and censors or the disruption that comes from encountering an old work in a new context. ${ }^{34}$ The gap between world-revealing and world-making within SF manifests as a paradox of genre. As we have seen, it is a commonplace to say that science fiction is really about the present. And as Stanislaw Lem argued, SF authors have historically not produced the grand projections that the genre licences, preferring the nearer horizons of the scientific advance-after-next or the setting for anthropological hypotheses (1981). ${ }^{35} \mathrm{SF}$ can be romantic and whimsical as readily as gothic or moralizing. And yet SF remains the literature of extrapolation. Its works both uncover recognisable truths and insist on inventing the unknown. Which is perhaps why so much of the SF canon may be upbraided both for mimicking the conditions of the $20^{\text {th }}$ century in all its prejudice and at the same time celebrated for indexing new futures. ${ }^{36}$

If speculative fictions were truly and only programmatic - if they mapped out not just the possibility of a different world but also the concrete means of getting there - they would be little better than the crude wish-lists of an aspirant Napoleon. Instead, SF endings regularly defer the realisation of the political programmes in question. For all the suggestive parallels we may discover in it, SF is after all unable to figure out real things, like the nature of the universe, precisely because it is forever throwing in its own 'what ifs' to flavour the recipe. ${ }^{37}$

\footnotetext{
34 For a rare discussion of the internal characteristics of genre, see Odysseos 2001.

35 Lem's own Solaris (released as a novel in 1961, then conjured on film first by Andrei Tarkovsky and then by Steven Soderbergh) is a study in the truly alien encounter, existentialist and hauntingly psychoanalytic.

36 Kilgore briefly considers touches on this tendency to both critique and celebrate, but does not pursue the point $(2010,18)$.

37 The line is borrowed from Brian Aldiss $(2013,56)$
} 
As Raymond Williams saw, the $20^{\text {th }}$ century turned against the romanticism of early utopias in favour of what he termed Putropia, utopias gone sour, emblematic of an elite class deeply suspicious of socialist dreams and proletarian agency (1988). ${ }^{38}$ Thus, even those strands of SF that have most emphatically lay out the programmatic sensibility can give way to a poetics of disenchantment, and flounder in the maw of reality.

As if to underline the centrality of the tension, the distinction between programme and expression can be found by another name in existing SF criticism. In 'Why Are Americans Afraid of Dragons?', an essay reflecting on the status of science fiction and fantasy, Le Guin herself proposed answers for someone who demanded to know the practical utility of imagination. The lesser answer, the 'next-to-truest' one, was that "the use of imaginative fiction...deepen[s] your understanding of the world, and your fellow men, and your own feelings, and your destiny" (Le Guin 1979, 43). This is the kind of answer that most all studies of popular culture in IR would prefer. The cultural archive is a practical tool, a great untapped database of political opinion (e.g. Dyson 2015), and a pool in which we can make out our reflection, with a little effort. But the truest answer for for Le Guin was something different, and less tangible for social scientific analysis. What, then, is the primary point of imagination? "The use of it is to give you pleasure and delight" (Le Guin 1979, 43). Something like this distinction - between understanding and delight - confronts any reading of a text (see also Brown 2001, 633; Holden 2003). The criticism of SF, and the project of pop-cultural IR, must then reckon anew with pleasure and delight.

\section{Dreams Must Explain Themselves}

It is possible to draw out how fantastical political echoes might become programmatic, or be taken up as programmatic by a given audience (e.g. Carpenter 2016). The criticisms of popcultural IR offered above should not, then, be interpreted as a closing down of methodological possibilities. They are, however, intended as a kind of revival of attention to the specific poetry of SF (Suvin 1988, 30). The distinction between the expressive and the programmatic,

38 Following the excellent suggestion of a reviewer, this intellectual point can also be experienced directly by watching the confounding cult SF film Zardoz (1974). 
and acknowledgement of their narrative intercourse, offers a new sensitivity to the interlaced currents of SF and IR (the distinction is not a dichotomy, but a clarification of tendencies working in parallel).

SF/IR confronts two kinds of limits. The first is in its own reductionism, where cultural artefacts come to represent or constitute a certain political message, more or less fixed, and legible from an exposition of character and plot. I have argued that this effaces a crucial difference in register between wonder and dogma, leading the field towards descriptivism and literalism rather than interpretation and criticism. The alternative is to be more alive to the richness of the speculative on its own terms. It bears repeating that this is not an evacuation of the political, but a nuancing of how we understand the relation of narrative to theory, ethics and political speech. Nor should the invocation of pleasure and delight be taken to imply that cultural affect is devoid of politics. On the contrary, our most immediate responses to aesthetics can also be thought of as profoundly shaped by political tradition, as prejudiced and pernicious as formal doctrine, and are therefore subject to cognition, critique and alteration. The point is simple: affective responses to SF require a method suited to their peculiar dynamics.

The second limit, implied by the first, is one of understanding. Even with a more subtle analytic lens, the aim of much pop-cultural IR remains an increase in the sum total of knowledge about the world through the consumption of cultural artefacts. It is indeed possible to trace the political in cultural form. Yet it also conceivable that speculative fictions may draw attention away from the 'real' objects which justify reflection in the first place. This is particularly so if both fictive and factual questions must be drastically simplified to fit the requirements of analogical reasoning. It is possible, in the richness of extrapolation, to be moved by culture, but moved away from understanding, elsewhere, not to purist escapism, but into the transfigured play of our knots of prejudice and hope, desire and fear, only obliquely perceptible. If SF is adjacent to politics, the angle at which it intersects may also deceive as to the shape of politics proper. 
Methodological implications follow. In the broadest terms, the argument presented here cautions strongly against closed textual analogies. The programmatic elements to be found in SF can indeed be revealed through a careful tracing of a single text, but esoteric readings which assume a system of correspondences between any given fiction and highly abstract features of international politics are likely to dilute both ingredients in the mixing. More damningly still, simplistic politicisation frequently makes IR approaches to literature "formulaic and predictable" (Holden 2003, 241). At the very least, drawing analogies in the standard manner requires an explicit defence of the plausibility and significance of correspondences identified, which is always likely to lead the investigator away from textual specifics towards authors, audiences and a more uneven architecture of meaning.

This is negative guidance: it instructs in what not to do. But onto this general disposition concrete methods may be grafted. To be included are those studies primarily concerned with the complexity of audience responses, and which do not privilege authorial intent or plot consistency, but instead show how viewers may superimpose meaning over a fragmented plot (e.g. Jackson and Nexon 2003). Studying audience controversies can thus work to subvert the apparent political certainties otherwise read into a work (most excellently, Hozic 2003). ${ }^{39}$ Fantastical narratives do not surrender their political truth under interrogation; rather we trace the content of politics through rival interpretations of the fantastical. The means of establishing how artefacts are received and reinterpreted will vary with methodological preference (again, see Carpenter 2016).

Within this framework SF/IR may also proceed as literary or cultural criticism, without the injunction to justify itself in terms of real world correspondences. Put otherwise, to take the perspective of the cultural critic rather than the political scientist, and all the special dilemmas that go with the role (see Collini 2013; Amaturo 1995; Holden 2003). Disciplinary IR does not have, or has lost, the tradition of the aesthetic essay. If the boundary between political theory proper and speculative fictions are as porous as is here claimed, there is no loss of insight in the process, since utopias, dystopias, putropias and their kin are all already

39 Hozic's discussion of aesthetic legitimation and political ambiguity in the reception of Stalker corroborates the recollections of Boris Strugatsky, co-author of the novel from which it is derived (2012). 
documents of the political. This approach is necessarily hermeneutic, its value lying in the interpretive energy brought to bear on the text. Since the performance of criticism itself imbues cultural artefacts with meaning, the test is not correspondence, but the change in perspective brought about by the criticism itself. There is in the distance somewhere a reliance on the view of culture as constitutive (see Neumann and Nexon 2006) to justify the exercise; depending on the philosophical givens, cultural readings may be understood as also diagnosing mass symptoms (as performed with great brio in Žižek 2008).

The interpretive impulse moreover encourages an inter-textual one, where individual examples are accorded less import than a network of fragments, motifs, still images and effects (most persuasively Shapiro 2009). Ideological meaning is found less in singular narrative unitary or a paired correspondence than in the recording of multiple structural similarities, decisive insofar as they promote a particular political sensibility, recognisable or inchoate. More than the insufficiency of the map to the territory, this style of reading takes as given that the relation of representation to represented is that of symbolic territories unevenly superimposed onto each other.

Dreams are rearrangements of reality, which may explain the preference for the metaphor of the mirror in IR discussions of SF artefacts. The mirror presents our image, reversed, a slight distortion, cut at the bevelled edge. Although about-face, the mirrored perspective is the most familiar, since persons can never see themselves from the outside (or, rather, only do so in the displacement provided by photograph and film). As Darko Suvin noted in describing the narrative effect of SF, "one needs a complex optical system in order to see oneself" (1988, $\mathrm{x})$. Our presence to ourselves is always established in reverse. The impersonation of the uncanny mirror effect is a standard trope of physical comedy, the illusion broken when the 'mirrored' party breaks away and acts independently, often behind the back of the person of whom they are the supposed reflection. Whilst not rejecting the notion that persons and societies may examine themselves closely in metaphorical mirrors, the relation is perhaps more akin to the scenario of China Miéville's The Tain, where what humans take to be their mirror-images are revealed as other-worldly imagos, alien doppelgängers caught in the 
gravity of polished surfaces, not unmediated reflections but sentient beings tortured into mimetic performance by the vanity of their beholders.

The relation of SF to IR is asymmetrical, but no less compelling for that. As one collection of SF criticism has it, the perspective of SF is best compared to a detached retina (Aldiss 2013). In attending to the expressive as well as the programmatic, the fragmented specimens of dreamworlds as much as formulaic correspondences, we may better parse the codes of culture beyond analogical appropriation: the strange and spectral demarcation of future worlds that are somehow already here, augmentations and mutilations, multiple immanences sent back in time to unsettle us, portending and refusing in equal measure, always ultimately in excess of analogy and political certainty. Parse them, but also get lost in their shadows and reverberations, revellers at the carnival.

\section{Acknowledgements}

With thanks to Jamie Allinson, Tarak Barkawi, Neta Crawford, Diego De Merich, Aggie Hirst, Myriam Fotou, Helen Kinsella, George Lawson, Aaron McKeil and Rorden Wilkinson for specific suggestions, criticisms and encouragement, and to participants at the Dystopias and Utopias panel at the International Studies Association Conference, February 2015; the IR502 seminar at the London School of Economics and Political Science, November 2015; and the Pop Culture and World Politics conference at the University of Westminster, December 2015. In some ways the thinking that informs this article began in the summer of 1996, just after I had acquired Frank Herbert's Dune in a second-hand book store in Washington, DC, for something like 50 cents. And so thanks to Steven Hardy-Braz for being my first guide.

\section{Bibliography}

Adorno, Theodor W. (2005) Minima Moralia: Reflections on a Damaged Life (London: Verso)

Aldiss, Brian (2013) [1995] The Detached Retina (London: The Friday Project) 
Amaturo, Winifred (1995) 'Literature and International Relations: The Question of Culture in the Production of International Power', Millennium: Journal of International Studies, 24 (1), pp. 1-25.

Amis, Kingsley (2012) [1960] New Maps of Hell: A Survey of Science Fiction (London: Penguin)

Ashworth, Lucian (2006) 'Where are the Idealists in Interwar International Relations?', Review of International Studies, 32 (2), pp. 291-308.

Asimov, Isaac (1981) Asimov on Science Fiction (Garden City, NY: Doubleday)

Atwood, Margaret (2011) In Other Worlds: SF and the Human Imagination (London: Virago)

Barboza, David (2011) 'Making TV Safer: Chinese Censors Crack Down on Time Travel', The New York Times, 12 April, available at http://artsbeat.blogs.nytimes.com/2011/04/12/making-tv-safer-chinese-censors-crack-downon-time-travel/

Barr, Marleen (1987) 'Feminist Fabulation; Or, Playing with Patriarchy vs. the Masculinization of Metafiction', Women's Studies, 14, pp. 187-191.

Barr, Marleen (2004) 'Textism: An Emancipatory Proclamation', PMLA, 119 (3), pp. 429441.

Bady, Aaron (2011) 'Tarzan's White Flights: Terrorism and Fantasy Before and After the Airplane', American Literature, 83 (2), pp. 305-329.

Baudrillard, Jean (1995) The Gulf War Did Not Take Place (Bloomington, IN: Indiana University Press)

Beaumont, Matthew (2009) 'The Anamorphic Estrangements of Science Fiction', in Mark Bould and China Miéville (eds.) Red Planets: Marxism and Science Fiction (London: Pluto Press, 2009)

Bleiker, Roland (2001) 'The Aesthetic Turn in International Political Theory', Millennium: Journal of International Studies, 30 (3), pp. 509-533.

Booth, Ken (1991) 'Security in Anarchy: Utopian Realism in Theory and Practice', International Affairs, 67 (3), pp. 527-545.

Bould, Mark (2007) 'The Ships Landed Long Ago: Afrofuturism and Black SF', Science Fiction Studies, 34 (2), pp. 177-186. 
Brennan, Kathleen P. J. (2015) 'MemeLife', in Mark B. Salter (ed.) Making Things International 1: Circuits and Motion (Minneapolis, MN: University of Minnesota Press)

Brincat, Shannon (2009) 'Reclaiming the Utopian Imaginary in IR Theory', Review of International Studies, 35 (3), pp. 581-609.

Brown, Chris (2001) “"Special Circumstances”: Intervention by a Liberal Utopia', Millennium: Journal of International Studies, 30 (3), pp. 625-633.

Brown, Chris (2002) 'The Construction of a 'Realistic Utopia': John Rawls and International Political Theory', Review of International Studies, 28 (1), pp. 5-21.

Bruce, Susan (2008) 'Introduction', in Three Early Modern Utopias: Utopia, New Atlantis and The Isle of Pines (Oxford: Oxford University Press)

Buzan, Barry (2010) 'America in Space: The International Relations of Star Trek and Battlestar Galactica', Millennium: Journal of International Studies, 39 (1), pp. 175-180.

Buzan, Barry and Lene Hansen (2009) The Evolution of International Security Studies (Cambridge: Cambridge University Press)

Callahan, William A. (2004) 'Remembering the Future - Utopia, Empire and Harmony in 21st-Century International Theory', European Journal of International Relations, 10(4), pp. 569-601.

Carpenter, R. Charli (2012) 'Game of Thrones as Theory', Foreign Affairs, 29 March, available at https://www.foreignaffairs.com/articles/2012-03-29/game-thrones-theory

Carpenter, R. Charli (2016) 'Rethinking the Political/-Science-/Fiction Nexus: Global Policy Making and the Campaign to Stop Killer Robots', Perspectives on Politics, 14(1), pp. 53-69.

Carpenter, R. Charli, Hrvoje Cvijanovic and Welsey Mason (2013) 'Security or Human Security? Civil-Military Relations in Battlestar Galactica', in Iver B. Neumann and Nicholas J. Kiersey (eds.) Battlestar Galactica and International Relations (Abingdon: Routledge)

Carr, Edward Hallett (2001) [1939] The Twenty Years' Crisis, 1919-1939: An Introduction to the Study of International Relations (Basingstoke: Palgrave Macmillan)

Clapton, William and Laura J. Shepherd (2016) 'Lessons from Westeros: Gender and Power in Game of Thrones', Politics, EarlyView

Collini, Stefan (2013) 'What, Ultimately, For? The Elusive Goal of Cultural Criticism', Raritan, 33 (2), pp. 4-26. 
Crane-Seeber, Jesse (2013) 'Seeing Others: Battlestar Galactica's Portrayal of Insurgents at a Time of War', in Iver B. Neumann and Nicholas J. Kiersey (eds.) Battlestar Galactica and International Relations (Abingdon: Routledge)

Crawford, Neta C. (2003) 'Feminist Futures: Science Fiction, Utopia, and the Art of Possibilities in World Politics', in Jutta Weldes (ed.) To Seek Out New Worlds: Science Fiction and World Politics (Basingstoke: Palgrave MacMillan)

Creed, Barbara (1993) The Monstrous-Feminine: Film, Feminism, Psychoanalysis (London: Routledge)

Csicsery-Ronay, Istvan (2007) 'Some Things We Know About Aliens', The Yearbook of English Studies, 27 (2), pp. 1-23.

de Laurentis, Teresa (2003) 'Becoming Inorganic', Critical Inquiry, 29 (4), pp. 547-570.

Dauphinee, Elizabeth (2013) The Politics of Exile (Abingdon: Routledge)

Delany, Samuel R. (1977) The Jewel-Hinged Jaw: Notes on the Language of Science Fiction (New York, NY: Berkley Windhover)

Der Derian, James (2009) Virtuous War: Mapping the Military-Industrial-MediaEntertainment Network, $2^{\text {nd }}$ Edition (Abingdon: Routledge)

Der Derian, James (2010) '"Now We Are All Avatars"', Millennium: Journal of International Studies, 39 (1), pp. 181-186.

Dittmer, Jason (2010) Popular Culture, Geopolitics, and Identity (Lanham, MD: Rowman and Littlefield)

Dittmer, Jason (2013) Captain American and the Nationalist Superhero: Metaphors, Narratives, and Geopolitics (Philadelphia, PA: Temple University Press)

Disch, Thomas M. (1998) The Dreams Our Stuff Is Made Of: How Science Fiction Conquered the World (New York, NY: Touchstone)

Drezner, Daniel (2011) Theories of International Politics and Zombies (Princeton, NJ: Princeton University Press)

Dyson, Stephen Benedict (2015) Otherworldly Politics: The International Relations of Star Trek, Game of Thrones, and Battlestar Galactica (Baltimore, MA: John Hopkins University Press)

Dyvik, Synne L. (2015) “"Valhalla Rising': Gender, Embodiment and Experience in Military Memoirs', Security Dialogue, 47 (2), pp. 133-150. 
Fey, Marco, Annika E. Poppe, and Carsten Rauch (2016) 'The Nuclear Taboo, Battlestar Galactica, and the Real World: Illustrations from a Science-Fiction Universe', Security Dialogue, 47 (4), pp. 348-365.

Franklin, H. Bruce (1988) War Stars: The Superweapon and the American Imagination (Oxford: Oxford University Press)

Franklin, H. Bruce (1990) 'The Vietnam War as American Science Fiction and Fantasy', Science Fiction Studies, 17 (3), pp. 341-359.

Freedman, Carl (1987) 'Science Fiction and Critical Theory', Science Fiction Studies, 14 (2), pp. 180-200.

Frye, Northrop (1965) 'Varieties of Literary Utopia', Daedalus, 94 (2), pp. 323-347.

Grayson, Kyle (2015) 'The Rise of Popular Culture in IR: Three Issues', e-IR, 30 January, available at: http://www.e-ir.info/2015/01/30/the-rise-of-popular-culture-in-ir-three-issues/

Grayson, Kyle, Matt Davies and Simon Philpott (2009) 'Pop Goes IR? Researching the Popular Culture-World Politics Continuum', Politics, 29 (3), pp. 155-163.

Hall, Martin (2006) 'The Fantasy of Realism, or Mythology as Methodology', in Daniel H. Nexon and Iver B. Neumann (eds.) Harry Potter and International Relations (Lanham, MA: Rowman and Littlefield)

Hallberg, Peter (2012) 'Thomas More's Cosmopolitanism Civil Science: The New World and Utopia Reconsidered', History of Political Thought, 33(4), pp. 578-606.

Hannah, Erin and Rorden Wilkinson (2014) 'Zombies and IR: A Critical Reading', Politics, OnlineFirst

Henne, Peter S. and Daniel H. Nexon (2013) 'Interpret This Volume! What We've Learned About Battlestar Galactica's International Relations Scholar-Fans', in Iver B. Neumann and Nicholas J. Kiersey (eds.) Battlestar Galactica and International Relations (Abingdon: Routledge)

Hindess, Barry (2007) 'The Past is Another Culture', International Political Sociology, 1 (4), pp. 325-38.

Holden, Gerard (2003) 'World Literature and World Politics: In Search of a Research Agenda', Global Society, 17(3), pp. 229-252.

Hollinger, Veronica (1987) 'Deconstructing the Time Machine', Science Fiction Studies, 14 (2), pp. 201-221. 
Hozic, Aida A. (2003) 'Forbidden Places, Tempting Spaces, and the Politics of Desire: On Stalker and Beyond', in Jutta Weldes (ed.) To Seek Out New Worlds: Science Fiction and World Politics (Basingstoke: Palgrave MacMillan)

Hutchings, Kimberly (2008) Time and World Politics: Thinking the Present (Manchester: Manchester University Press)

Inayatullah, Naeem (2003) 'Bumpy Space: Imperialism and Resistance in Star Trek: The Next Generation', in Jutta Weldes (ed.) To Seek Out New Worlds: Science Fiction and World Politics (Basingstoke: Palgrave MacMillan)

Inayatullah, Naeem and Elisabeth Dauphinee (eds.) (2016) Narrative Global Politics: Theory, History and the Personal in International Relations (Abingdon: Routledge)

Jackson, Patrick Thaddeus (2013) 'Critical Humanism: Theory, Methodology and Battlestar Galactica', in Iver B. Neumann and Nicholas J. Kiersey (eds.) Battlestar Galactica and International Relations Abingdon: Routledge)

Jackson, Patrick Thaddeus and Daniel H. Nexon (2003) 'Representation is Futile? American Anti-Collectivism and the Borg', in Jutta Weldes (ed.) To Seek Out New Worlds: Science Fiction and World Politics (Basingstoke: Palgrave MacMillan)

Jackson, Rosemary (1981) Fantasy: The Literature of Subversion (London: Methuen) Jameson, Frederic (2005) Archaeologies of the Future: The Desire Called Utopia and Other Science Fictions (London: Verso)

Jeffords, Susan (1989) The Remasculinization of America: Gender and the Vietnam War (Bloomington, IN: Indiana University Press)

Kiersey, Nicholas J. and Iver B. Neumann (2013) 'Circulating On Board the Battlestar', in Iver B. Neumann and Nicholas J. Kiersey (eds.) Battlestar Galactica and International Relations (Abingdon: Routledge)

Kilgore, De Witt Douglas (2010) 'Difference Engine: Aliens, Robots, and Other Racial Matters in the History of Science Fiction', Science Fiction Studies, 37 (1), pp. 16-22.

Le Guin, Ursula K. (1975) 'American SF and the Other', Science Fiction Studies, 2 (3), pp. 208-210.

Le Guin, Ursula K. (1979) 'Why Are Americans Afraid of Dragons?', in The Language of the Night: Essays on Fantasy and Science Fiction (New York, NY: Putnam Books)

Le Guin, Ursula K. (1989) 'Is Gender Necessary?', in in The Language of the Night: Essays on Fantasy and Science Fiction, revised edition (London: Women's Press) 
Lem, Stanislaw (1981) 'Metafantasia: The Possibilities of Science Fiction', Science Fiction Studies, 8 (1), pp. 54-71.

Levitas, Ruth (1990) 'Educated Hope: Ernst Bloch on Abstract and Concrete Utopia', Utopian Studies, 1 (2), pp. 13-26.

Lipschutz, Ronnie D. (2003) 'Aliens, Alien Nations, and Alienation in American Political Economy and Popular Culture', in Jutta Weldes (ed.) To Seek Out New Worlds: Science Fiction and World Politics (Basingstoke: Palgrave MacMillan)

Livingston, Dennis (1971) 'Science Fiction Models of Future World Systems', International Organization, 25 (2), pp. 254-270.

Long, David (2006) 'Quidditch, Imperialism, and the Sport-War Intertext', in Daniel H. Nexon and Iver B. Neumann (eds.) Harry Potter and International Relations (Lanham, MA: Rowman and Littlefield)

Maisonville, Derek (2013) 'So Say Who All? Cosmopolitanism, Hybridity, and Colonialism in the Re-Imagined Battlestar Galactica', in Iver B. Neumann and Nicholas J. Kiersey (eds.) Battlestar Galactica and International Relations (Abingdon: Routledge)

Mamatas, Nick (2008) 'Holy Signifier, Batman!', in Dennis O’Neil with Leah Wilson (eds.) Batman Unauthorized: Vigilantes, Jokers, and Heroes in Gotham City (Dallas, TX:

BenBella Books)

May, Clifford D. (2011) 'The Marilyn Monroe Doctrine', National Review, 14 July.

Miéville, China (2009) 'Cognition as Ideology: A Dialectic of SF Theory' in Mark Bould and China Miéville (eds.) Red Planets: Marxism and Science Fiction (London: Pluto Press)

Miéville, China (2012) 'On Monsters: Or, None or More (Monstrous) Not Cannies', Journal of the Fantastic in the Arts, 23 (3), pp. 377-392.

Miéville, China (2015) 'The Limits of Utopia', Salvage, 1, pp. 117-130.

Miéville, China (2016) “'We are all Thomas More's children: 500 years of Utopia', The Guardian, 4 November, available at:

https://www.theguardian.com/books/2016/nov/04/thomas-more-utopia-500-years-china$\underline{\text { mieville-ursula-le-guin }}$

Miller, Mark Crispin (1976) 'Barry Lyndon Reconsidered', The Georgia Review, 30 (4), pp. 827-853.

Molloy, Patricia (2003) 'Demon Diasporas: Confronting the Other and the Other-Worldly in Buffy the Vampire Slayer and Angel', in Jutta Weldes (ed.) To Seek Out New Worlds:

Science Fiction and World Politics (Basingstoke: Palgrave MacMillan) 
Mydans, Seth (2014) 'Thai Protestors Are Detained After Using 'Hunger Games' Salute', The New York Times, 20 November, available at:

http://www.nytimes.com/2014/11/21/world/asia/thailand-protesters-hunger-gamessalute.html

Nama, Adilifu (2008) Black Space: Imagining Race in Science Fiction Film (Austin, TX: University of Texas Press)

Neumann, Iver B. (2001) “'Grab a Phaser, Ambassador”: Diplomacy in Star Trek', Millennium: Journal of International Studies, 30 (3), pp. 603-624.

Neumann, Iver B. (2013) "Religion in Sort of a Global Sense": The Relevance of Religious Practices for Political Community in Battlestar Galactica and Beyond', in Iver B. Neumann and Nicholas J. Kiersey (eds.) Battlestar Galactica and International Relations (Abingdon: Routledge)

Neumann, Iver B. and Daniel H. Nexon (2006) 'Harry Potter and the Study of World Politics', in Daniel H. Nexon and Iver B. Neumann (eds.) Harry Potter and International Relations (Lanham, MA: Rowman and Littlefield)

Nexon, Daniel H. (2007) 'Magical Realism: How Harry Potter Explains the World', The New Republic, 16 July, available at: https://newrepublic.com/article/63433/magical-realism

NPR (2011) 'Star Trek's Uhura Reflects on MLK Encounter', npr.org, available at: http://www.npr.org/2011/01/17/132942461/Star-Treks-Uhura-Reflects-On-MLK-Encounter

Odysseos, Louiza (2001) 'Laughing Matters: Peace, Democracy and the Challenge of the Comic Narrative', Millennium: Journal of International Studies, 30(3), pp. 709-732.

Onuf, Nicholas (1994) 'Imagined Republics', Alternatives: Global, Local, Political, 19 (3), pp. 315-337.

Ricoeur, Paul (1979) 'The Function of Fiction in Shaping Reality', Continental Philosophy Review, 12 (2), pp. 123-141.

Ruane, Abigail E. and Patrick James (2012) The International Relations of Middle Earth: Learning from The Lord of the Rings (Ann Arbor, MI: Michigan University Press)

Russ, Joanna (1975) 'Towards an Aesthetic of Science Fiction', Science Fiction Studies, 2 (2), pp. 112-119.

Russ, Joanna (1995) To Write Like A Woman: Essays in Feminism and Science Fiction (Bloomington, IN: Indiana University Press) 
Rowley, Christina and Jutta Weldes (2012) 'The Evolution of International Security Studies and the Everyday: Suggestions from the Buffyverse', Security Dialogue, 43 (6), pp. 513530 .

Salter, Mark (2011) 'The Geographical Imaginations of Video Games: Diplomacy, Civilization, America's Army and Grand Theft Auto IV', Geopolitics, 16 (2), pp. 359-388.

Sargent, Lyman Tower (1994) 'The Three Faces of Utopianism Revisited', Utopian Studies, 5(1), pp. 1-37.

Seed, David (2010) 'The Course of Empire: A Survey of the Imperial Theme in Early Anglophone Science Fiction', Science Fiction Studies, 37 (2), pp. 230-252.

Segal, Lynne (1998) 'Only the Literal: The Contradictions of Anti-Pornography Feminism' Sexualities, 1(1), pp. 43-62.

Shapiro, Michael J. (1989) 'Representing World Politics: The Sport/War Intertext' in James Der Derian and Michael J. Shapiro (eds.) International/Intertextual Relations: Postmodern Readings of World Politics (New York, NY: Lexington Books)

Shapiro, Michael J. (1997) Violent Cartographies: Mapping Cultures of War (Minneapolis, MN: University of Minnesota Press)

Shapiro, Michael J. (2009) Cinematic Geopolitics (Abingdon: Routledge).

Shaviro, Steven (2016) Discognition: Fictions and Fabulations of Sentience (London: Repeater)

Shklar, Judith (1965) 'The Political Theory of Utopia: From Melancholy to Nostalgia', Daedalus, 94 (2), pp. 367-381.

Shepherd, Laura J. (2013) Gender, Violence and Popular Culture: Telling Stories (Abingdon: Routledge)

Sontag, Susan (1965) 'The Imagination of Disaster', Commentary, October, pp. 42-48

Stead, W. T. (1902) The Last Will and Testament of Cecil John Rhodes, with Elucidatory Notes to Which Are Added Some Chapters Describing the Political and Religious Ideas of the Testator (London: William Clowes and Sons)

Sterling-Folker, Jennifer and Brian Folker (2006) 'Conflict and the Nation-State: Magical Mirrors of Muggles and Refracted Images', in Daniel H. Nexon and Iver B. Neumann (eds.) Harry Potter and International Relations (Lanham, MA: Rowman and Littlefield)

Strugatsky, Boris (2012) 'Afterward', in Arkady Strugatsky and Boris Strugatsky, Roadside Picnic (London: Gollanz) 
Suvin, Darko (1988) Positions and Presuppositions in Science Fiction (Basignstoke: Macmillan Press)

Towns, Ann and Bahar Rumelili (2006) 'Foreign Yet Familiar: International Politics and the Reception of Potter in Turkey and Sweden', in Daniel H. Nexon and Iver B. Neumann (eds.) Harry Potter and International Relations (Lanham, MA: Rowman and Littlefield)

Weber, Cynthia (1999) 'IR: The Resurrection; Or, New Frontiers of Incorporation', European Journal of International Relations, 5 (4), pp. 435-450.

Weber, Cynthia (2001) 'The Highs and Lows of Teaching IR Theory: Using Popular Films for Theoretical Critique', International Studies Perspectives, 2 (3), pp. 281-287.

Weldes, Jutta (1999) 'Going Cultural: Star Trek, State Action and Popular Culture', Millennium: Journal of International Studies, 28 (1), pp. 117-134.

Weldes, Jutta (2001) 'Globalisation is Science Fiction', Millennium: Journal of International Studies, 30 (3), pp. 647-667.

Weldes, Jutta (2003) 'Popular Culture, Science Fiction, and World Politics: Exploring Intertextual Relations', in Jutta Weldes (ed.) To Seek Out New Worlds: Science Fiction and World Politics (Basingstoke: Palgrave MacMillan)

Wells, H.G. (2005) [1933] The Shape of Things to Come: The Ultimate Revolution (London: Penguin)

Wendt, Alexander and Raymond Duvall (2008) 'Sovereignty and the UFO', Political Theory, 36 (4), pp. 607-633.

Whitehall, Geoffrey (2003) 'The Problem of the "World and Beyond": Encountering "the Other" in Science Fiction', in Jutta Weldes (ed.) To Seek Out New Worlds: Science Fiction and World Politics (Basingstoke: Palgrave MacMillan)

Wilcox, Lauren (2013) 'Machines That Matter: The Politics and Ethics of "Unnatural" Bodies', in Iver B. Neumann and Nicholas J. Kiersey (eds.) Battlestar Galactica and International Relations (Abingdon: Routledge)

Wight, Martin (1991) International Theory: The Three Traditions, Gabriele Wight and Brian Porter (eds.) (Leicester: University of Leicester Press)

Williams, R. John (2016) ‘World Futures’, Critical Inquiry, 42(3), pp. 473-546.

Williams, Raymond (1978) 'Utopia and Science Fiction', Science Fiction Studies, 5 (3), pp. 203-214. 
Williams, Raymond (1988) [1956] 'Science Fiction', Science Fiction Studies, 15 (3), pp. 356-360.

Yogerst, Chris (2013) 'Stop Calling Superheroes "Fascist”, The Atlantic, 3 December, available at http://www.theatlantic.com/entertainment/archive/2013/12/stop-callingsuperheroes-fascist $/ 281985 /$

Žižek, Slavoj (1989) ‘Looking Awry’, October, 50, pp. 30-55.

Žižek, Slavoj (2008) [1992] Enjoy Your Symptom!: Jacques Lacan in Hollywood and Out (Abingdon: Routledge) 